\title{
Dutch Disease Symptoms in Mongolian Economy and Ways to reduce its Negative Effects
}

\author{
Lkhagvaa Dansranbavuu ${ }^{1}$, Sodnomdavaa Tsolmon ${ }^{2}$ and Enkhchimeg Tsedendori ${ }^{3}$ \\ ${ }^{1-3}$ Lectures at Mandakh Burtgel University, Mongolia
}

\begin{abstract}
Background/Objectives: Mongolia has plenty of natural resources and comparatively few populations of 3 million, most of them are younger. It means Mongolia has a lot of opportunities to grow its economy quickly and compete with other countries by an economic growth. But, Mongolian economy has been stagnated in last few years since reaching the peak growth at 17.5 percent in 2011. Methods/Statistical analysis: We assume that the main reason for an economic stagnation caused by the government bad decisions not basing on the scientific research. The Dutch disease theory explains the relationship between increasing and declining specific sectors, which resulting in the currency appreciation. Findings: This paper aims to determine that the reason for economic difficulties and make some suggestion to prevent the worsening situation. Improvements/Applications: As of Mongolia, it has been reflected by Dutch disease very badly, so need to find the way to dive into the right paths.
\end{abstract}

\section{Index Terms}

Economic policy, Dutch disease, Mongolian economy, Resource curse, Budget expansion

\footnotetext{
Corresponding author : Enkhchimeg Tsedendorj

chimge2002@must.edu.mn

- Manuscript received June 15, 2018.

- Revised July 13, 2018 ; Accepted September 7, 2018.

- Date of publication September 30, 2018.

(C) The Academic Society of Convergence Science Inc.

2546-1583 @ 2017 IJEMR. Personal use is permitted, but republication/redistribution requires IJEMR permission.
} 


\section{INTRODUCTION}

The rapid economic growth in a specific sector influences on the whole economy in both positive and negative ways[1,2]. The increase in export revenue manipulates public sector investments, creates jobs and implements public projects, which were impossible in previous economic conditions. In reality, the revenue growth becomes the reason to increase government expenses. Consequently, it affects the state budget to expand and influences to increase the consumption quickly. Briefly, it is called as Dutch disease symptoms in an economy[3,4,5].

\section{The Dutch Disease}

The first research paper published in the Economist in 1977, which points out that how does the mining of natural gas explored in 1959, influence on country's whole economy. The article used the terminology of Dutch disease for the first time [6]. Emphasizing on a natural gas mining helps Dutch government to increase its budget revenue, on the contrary, it decreased the production and jobs in non-gas sectors.

The government increased public expenditures to eliminate these negative effects by providing social welfares for many unemployed people in non-gas sectors. Eventually, the budget deficit became larger and inflation rate became worse that all causes the number of increase in poverty and crime.

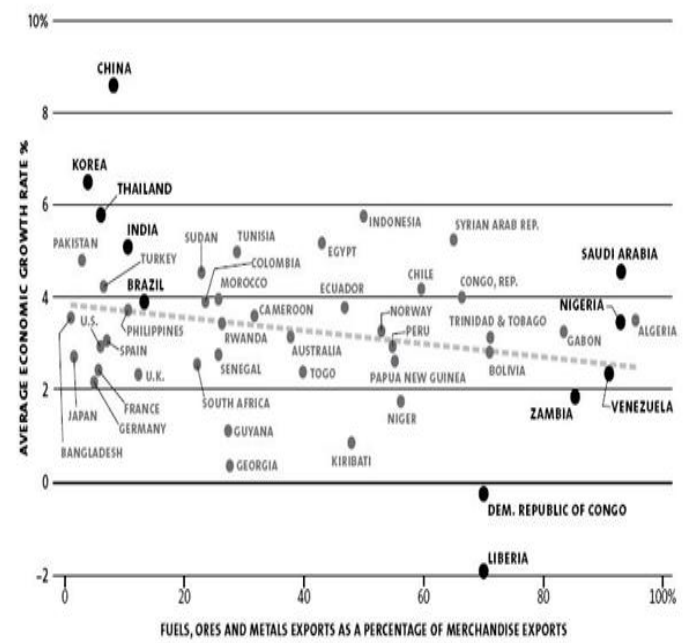

Figure 1. Mineral exports and growth, 1970-2008 (Source: World Development Indicators, World Bank)

At the early stages, the increase in the mining sector of the development attracts the foreign direct investment and creates more jobs. We need to emphasize on the number of jobs have been created by the mining sectors comparing to the other sectors.

It actually creates fewer jobs than others and it does not affect the total employment rate. If government and citizens believe that this situation will continue forever and plan the economy, it leads to a huge risk [7].

As calculation by World Bank as shown on graph 1, if a particular country's export is high dependable to the natural resources, then it will have a low growth rate. It means that the country can use the development of mining sector in early stages, but not forever

\section{ECONOMIC BACKGROUND OF MONGOLIA}

In 2010-2016, Mongolian real GDP expressed by the price of 2010 increased from 9.8 to 16.0 billion tugriks and by 63.3 percent. Unfortunately, Government of Mongolia is discussing with IMF on launching its Extended Fund Facility program, because of lack of foreign currency reserve to pay previous bond repayments and cover increasing the budget deficit.

There are several studies on Dutch disease in Mongolia. For example, Gan-Ochir noted that "There are hidden and seasonal symptoms of Dutch disease in Mongolian economy and if the prices of gold and copper, main export products of Mongolia continue to increase and new mining of copper and gold are started exploration, then it may influence on tugrik's real exchange rate appreciation and weakness of export production sectors except mining" [8]. On another one study, Avralt-Od and others mentioned that "Some clear symptoms of the Dutch disease are discovered in Mongolian economy from 2010. High growth of mining sector and its supply sectors, an excessive demand for non-tradable goods, and budget expansion became the result of high inflation" [9]. And researchers suggested creating the "Natural Resource Foundation" to diversify additional financial resources of the booming mining sector and to implement budget-tightening policies combining with monetary expansion policies. Ariunaa and Kim attempted to diagnose Dutch disease in Mongolian economy and concluded that the diagnosis of Dutch Disease cannot be confirmed even though Mongolia may be characterized by all these symptoms [10].

There are other several studies about Dutch disease symptoms in Mongolian economy and all of the studies reached controversial results.

One of the main characters to define Dutch disease symptoms on country's economy is real exchange rate and its appreciation. As a report of BoM, between the end of 2000 and 2015, tugrik's REER was appreciated by 83.78 percent when its NEER was depreciated by 41.72 percent.

The second character of Dutch disease is a lower growth rate of manufacturing sector comparing to higher growth of booming mining sector and its supply sectors. 


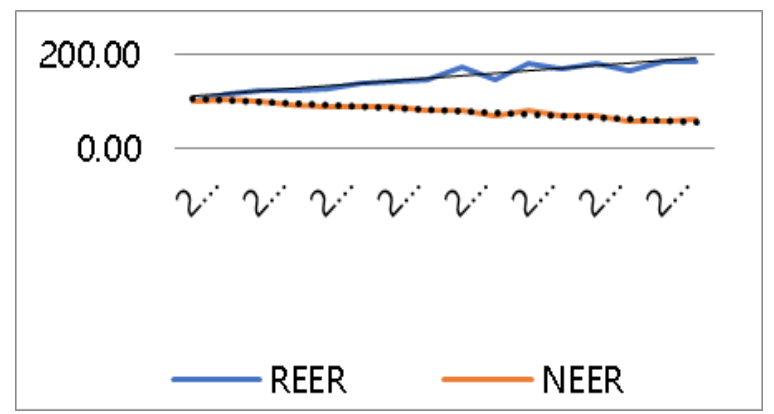

Figure 2. REER and NEER, by percentage (Source: Bank of Mongolia)

Following graph shows that the growth rates of real GDP and mining sector have a growing tendency when the growth rate of manufacturing has a decreasing tendency in 2000-2016 in Mongolia.

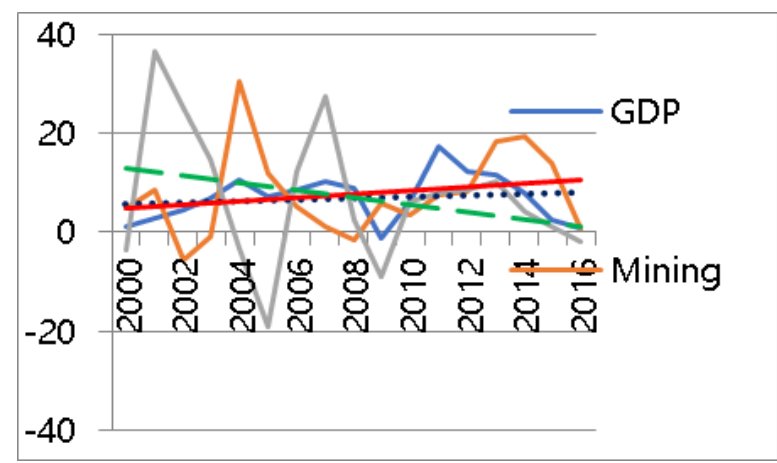

Figure 3. Real growth rate of GDP, mining and manufacturin g sectors' production, by percentage (Source: National Statistic s Office of Mongolia)

The third indicator of Dutch disease symptom is a growth of average salary depending on more demand of skilled labors in booming sectors. Graph 4 shows that the real average salary has increased 3 times in 2005-2015. At the same time, the real GDP has not grown same times.

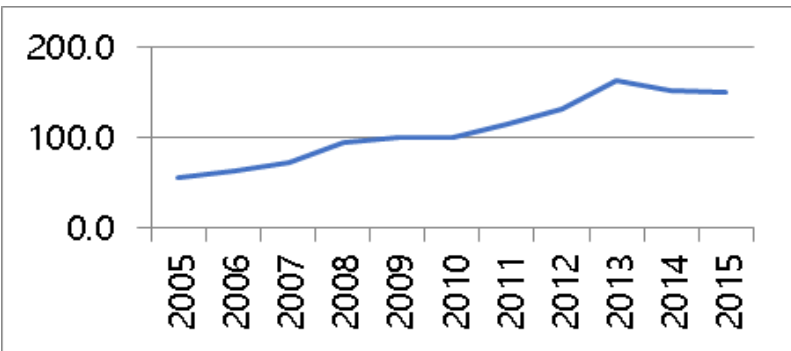

Figure 4. Index of real average salary, salary of 2010 is 100 percent (Source: National Statistics Office of Mongolia)

Quickly considering at above data, it seems Mongolia has some symptoms of Dutch disease. So, here main goals of the paper to testify that does Dutch disease exist practically and define some policies to remedy them appear.

\section{METHODS}

W.Max Corden and J. Peter Neary explained Dutch disease by an economic model. They divided the country's economy into 2 main sectors as booming sectors and others. Furthermore, the non-booming sectors are divided into tradable and non-tradable sectors.

The more revenue of booming sector creates 2 kinds of effects on the economy, first, "resource movement effect" from non-booming sector to booming sector and its supply sectors, and second, "spending effect" increasing the money supply as loosening loan policies and expanding social welfares.

These policies influence on the price increase for non-tradable goods sharply, but prices for tradable goods cannot be increased because of international market equilibrium and demand.

After all, REER of domestic currency will be appreciated and the competing capacity of tradable goods in a worldwide market will decrease [11].

$$
D D_{\text {manufacturing }}=F(R M E, S E), \text { here: }
$$

$D D_{\text {manufacturing }}$ : Dutch disease in manufacturing sector RME : Resource movement effect SE : Spending effect

There are a lot of studies challenging different empirical models. In our study, we examine real exchange rate, whether copper price and quick growth of GDP cause the Dutch disease in Mongolian economy.

This paper employed macroeconomic quarterly data on the exchange rate, copper price, gross domestic product, and trade balance in 2000-2015. We used data resource as calculation of Bank of Mongolia for tugrik's real exchange rate, data of www.macrotrends.net for copper price, data of National Statistic Office of Mongolia for gross domestic product and trade balance.

The trade balance is calculated by taking the ratio of import and export of Mongolia and then taken into logarithmic form. So regression equation is:

$\ln \left(\mathrm{REER}_{t}\right)=\alpha+\beta_{1} \ln \left(\mathrm{CP}_{t}\right)+\beta_{2} \ln \left(\mathrm{GDP}_{t}\right)+\beta_{3} \ln \left(\mathrm{TB}_{t}\right)+\varepsilon_{t}(1)$

In REER : real exchange rate index in logarithm (tugriks per USD)

$\ln (\mathrm{CP}) \quad$ : Copper price in logarithm (USD per tonn)

$\ln$ (GDP) : Real GDP in logarithm (expressed by $2005 \mathrm{MNT}$ )

$\ln$ (TB) : Trade balance in logarithm (logEXP-logIMP in USD)

\& : :rror term 


\section{EMPIRICAL FINDINGS AND RESULTS}

We used tugrik's real effective exchange rate per USD in logarithm, Ln(REER) as a dependent variable, and copper price in logarithm, $\operatorname{Ln}(\mathrm{CP})$, nominal GDP in logarithm, $\mathrm{Ln}(\mathrm{GDP})$ and foreign trade balance in logarithm, $\mathrm{Ln}(\mathrm{TB})$ as dependent variables.

Sampling data of Bank of Mongolia and National Statistics Office of Mongolia were used and data span covers the period from the 1 st quarter, 2000 to 1 st quarter, 2016. Total 65 quarterly data are used to evaluate the econometric model.

At first, we checked linear relationships between copper price and GDP, the real exchange rate of tugrik and trade balance of Mongolia.
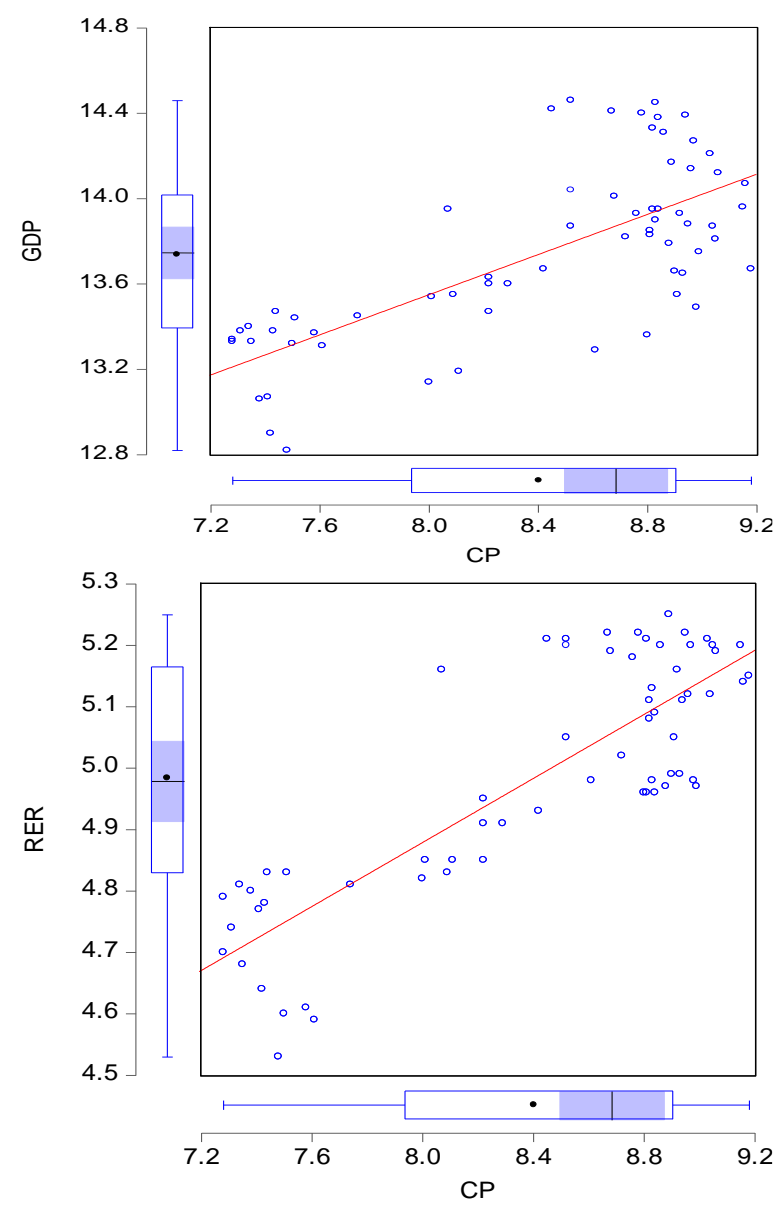

Figure 5. Copper price and GDP, RER scatter diagram

We observe that there is strong, positive linear relationship between copper price and GDP, RER of tugriks and weak, negative linear relationship between copper price and trade balance.

Regression results using OLS method are shown in table 1 . For the equation 1 , adjusted R-square is high of 0.830792 , but trade balance is not statistically significant. So we eliminated the data of trade balance and the result is shown as equation (2) column on table 1 .

Table 1. Regression RESUlts Using OLS METHOD

\begin{tabular}{|c|c|c|c|c|}
\hline Independent & Equation (1) & & Equation (2) & \\
\hline variables & Coefficient & $\mathrm{t}$-Statistic & Coefficient & t-Statistic \\
\hline \multirow{2}{*}{ Constant } & 0.454441 & 1.202189 & 0.425676 & 1.152074 \\
\hline & $0.146278^{* * * *}$ & 6.262514 & $0.146745^{* * *}$ & 6.331314 \\
\hline $\operatorname{Ln}(\mathrm{CP})$ & $0.240473^{* * *}$ & 6.780240 & $0.242030^{* * *}$ & 6.906263 \\
\hline \multicolumn{5}{|l|}{ Ln(GDP) } \\
\hline $\operatorname{Ln}(\mathrm{TB})$ & 0.021016 & 0.426588 & & \\
\hline \multicolumn{5}{|l|}{$\begin{array}{l}\text { Adjusted } \quad \text { R- } \\
\text { squared }\end{array}$} \\
\hline \multicolumn{5}{|l|}{$\begin{array}{l}\text { S.E. } \\
\text { regression }\end{array}$} \\
\hline & 0.081955 & & 0.081412 & \\
\hline & $99.83408^{* * *}$ & & $151.6611^{* * *}$ & \\
\hline \multicolumn{5}{|l|}{$\begin{array}{l}\text { Akaike info } \\
\text { criterion }\end{array}$} \\
\hline \multirow{2}{*}{ Observations } & -2.105737 & & -2.133528 & \\
\hline & 65 & & 65 & \\
\hline
\end{tabular}

$\mathrm{t}$ statistics in parentheses: $* \mathrm{p}<0.05, * * \mathrm{p}<0.01, * * *$ $\mathrm{p}<0.001$

After both regressions, we can see that equation 2 is better described the situation and has higher statistical significance comparing to first equation while the meaning of adjusted R-square was decreased a little bit, but the value of F-statistics increased to 151.6611.

From the regression result, we can conclude that strong, positive linear relationship between RER of tugriks per USD and GDP, copper price exists. And trade balance has a negative, weak effect on RER of tugriks.

Each 1 percent increase in copper price increases RER by 0.146745 percent, each 1 percent increase in nominal GDP increases RER by 0.242030 percent. Copper price has the significant effect on RER and it shows that first hypothesis of Dutch disease are proven.

After that, we used Johansen Cointegration test to check there is the long term relationship between these variables. Attachment 2 shows us there is not a long term relationship.

Second criteria to evaluate Dutch disease symptoms is labor movement between economic sectors depending on mining sector production, copper, and coal export revenues.

For this purpose, we used labor data of economic sectors from National Statistics Office, and data of mining production, copper, and coal export revenue from Mongolian Custom Office. 
Table 2. LABOR MOVEMENT BETWEEN ECONOMIC SECTORS AND MINING EXPORT REVENUES

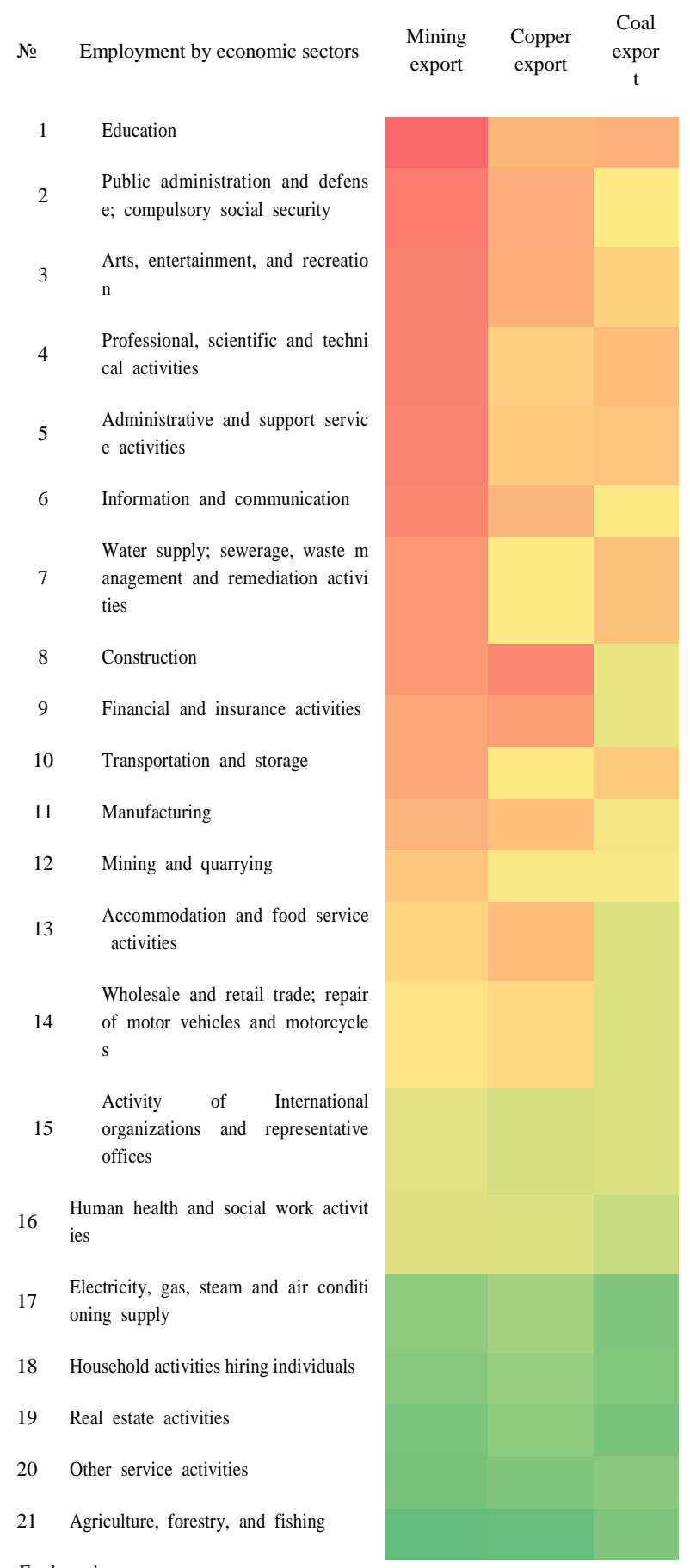

Explanation

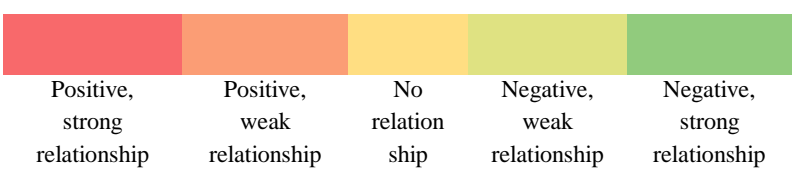

Table 2 shows that copper, coal, and mining export increase influence on labor movement of sectors in different ways.

We divided economic sectors into 3 segments after evaluating the relationships using a correlation method. In other words, there are some economic sectors, where positive (strong and weak) relationships with mining and main minerals' export increase, some sectors have no relationships, and some economic sectors, where there are negative (strong and weak) relationships with an increase of mining and main minerals' exports.

For example, increase of mining, copper and coal export creates more employment in sectors of education, public administration and defense; compulsory social security, arts, entertainment and recreation, professional, scientific and technical activities, administrative and support service activities, information and communication and reduces the employment in sectors of agriculture, forestry and fishing, real estate activities, other service activities depending on strong and negative relationships.

So, we can say that mining export increase creates labor movement between economic sectors. Also, it proves the second hypothesis of Dutch disease symptoms in Mongolian economy.

Additionally, table 3 shows that the relationships between mining exports increase and GDP and production of economic sectors and proves that mining export revenue increase has a strong, positive influence on some non-tradable goods sectors, and has negative effects on most of the tradable goods sectors and symptoms of Dutch disease in Mongolian economy.

Table 3. Relationship between GDP, pRoduction of MAIN ECONOMIC SECTORS AND MINING EXPORT REVENUES

\begin{tabular}{|c|c|c|c|c|}
\hline № & GDP by economic sectors & $\begin{array}{l}\text { Mining } \\
\text { export }\end{array}$ & $\begin{array}{l}\text { Copper } \\
\text { export }\end{array}$ & $\begin{array}{l}\text { Coal } \\
\text { export }\end{array}$ \\
\hline 1 & Total & & & \\
\hline 2 & Mining and quarrying & & & \\
\hline 3 & Net taxes on products & & & \\
\hline 4 & $\begin{array}{l}\text { Wholesale and retail trade; repair of } \\
\text { motor vehicles and motorcycles }\end{array}$ & & & \\
\hline 5 & $\begin{array}{l}\text { Professional, scientific and technical a } \\
\text { ctivities }\end{array}$ & & & \\
\hline 6 & Construction & & & \\
\hline 7 & $\begin{array}{l}\text { Public administration and defense; co } \\
\text { mpulsory social security }\end{array}$ & & & \\
\hline 8 & Transportation and storage & & & \\
\hline 9 & Other service activities & & & \\
\hline 10 & Information and communication & & & \\
\hline
\end{tabular}




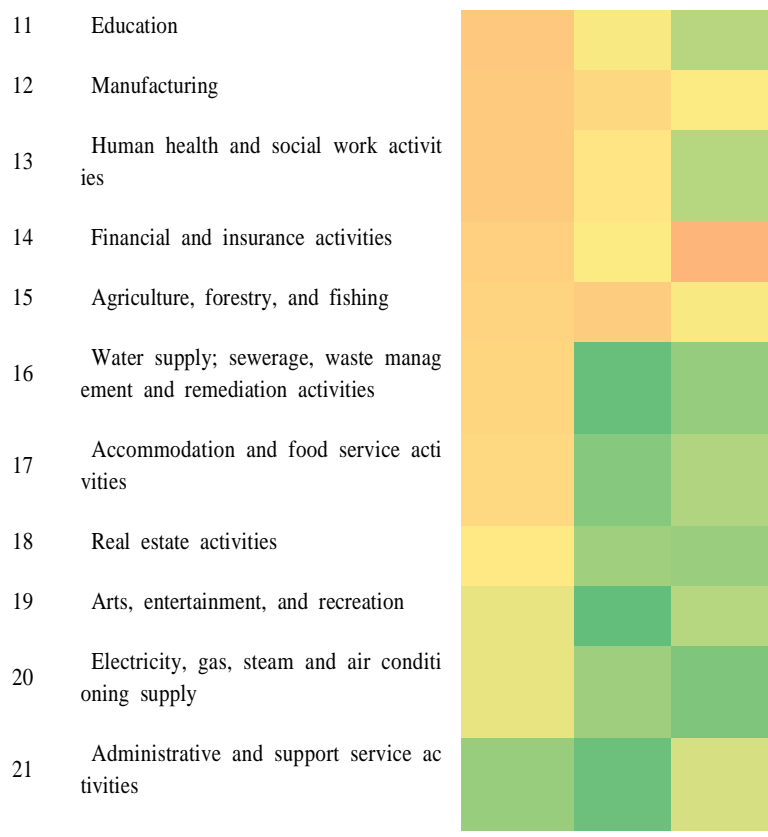

\section{Conclusion ANd Future DISCUSSIONS}

The price increase of copper, one of the main sources of Mongolian export revenue has strong and positive relationships with GDP and real exchange rate of tugriks per a USD. It proves that the first hypothesis of Dutch disease symptoms.

Later, we checked how do labor movements between economic sectors depend on an export revenue increase of mining, copper, and coal, and have divided into 3 segments. The result shows that export revenue increase of mining, copper and coal influences on employment increase on education; public administration and defense, compulsory social security; and arts, entertainment, and recreation sectors and on employment decrease on agriculture, forestry and fishing sector, and proves the second hypothesis of Dutch disease symptoms.

Until 2011, the average salary and employment on mining sector have increased, but the sector has not much capacity to employ more people comparing to other sectors like agriculture. Also after 2011, the peak growth of Mongolian economy, the production decrease of the sector created mid-term unemployment.

To reduce Dutch disease symptoms, before all, we need policies to reduce real exchange rate appreciation growth. Meanwhile, promotion policies to support decreasing sectors, which have more capacity to offer more jobs, are required.

Some economic sectors are growing and some are decreasing depending on the rapid growth of mining sector. This situation urges us to implement coherent monetary and fiscal policies. Whole Mongolian economy depends on export revenue of few minerals and world price, not on an exchange rate. In order to reduce these vulnerabilities, economic diversification policies are urgently required.

\section{REFERENCES}

[1] Park, S. T., Im, H., \& Noh, K. S. (2016). A study on factors affecting the adoption of LTE mobile communication service: The case of South Korea. Wireless Personal Communications, 86(1), 217-237.

[2] Li, G., \& Park, S. (2017). A Study on Patent Valuation Factors. International Journal of Emerging Multidisciplinary Research, 1(2), 15-21 [DOI: 10.22662/IJEMR.2017.1.2.015].

[3] Bruno, M., \& Sachs, J. (1982). Energy and resource allocation: a dynamic model of the "Dutch Disease". The Review of Economic Studies, 49(5), 845-859.

[4] Corden, W. M. (1984). Booming sector and Dutch disease economics: survey and consolidation. oxford economic Papers, 36(3), 359-380.

[5] Krugman, P. (1987). The narrow moving band, the Dutch disease, and the competitive consequences of Mrs. Thatcher: Notes on trade in the presence of dynamic scale economies. Journal of development Economics, 27(1-2), 41-55.

[6] Economist, T. (1977). The dutch disease. The Economist, 82.

[7] Banks, G. (2011, June). Australia's mining boom: what's the problem, In Melbourne Institute and The Australian Economic and Social Outlook Conference (Vol. 30).

[8] Gan-Ochir.D. (2009). Monetary Index calculation in Mongolian economy: Monetary policy is tightening or loosening?, Research paper of Bank of Mongolia.

[9] Avralt-Od.P. Gan-Ochir.D., \& etc. (2012). The Dutch disease symptoms in Mongolian economy. Research paper volume of Mongol Bank, 8, 88-143.

[10] Ariunaa, K., \& Kim, H. J. (2011). Diagnosing dutch disease: does Mongolia have the symtoms.

[11] Corden, W. M., \& Neary, J. P. (1982). Booming sector and de-industrialisation in a small open economy. The economic journal, 92(368), 825-848.

\section{ATTACHMENTS}

Attachment 1. Ordinary Least Squares regression results

Dependent Variable: REER

Method: Least Squares

Date: 04/13/17 Time: 13:03

Sample: 2000Q1 2016Q1

Included observations: 65

\begin{tabular}{ccccc}
\hline \hline Variable & Coefficient & Std. Error & t-Statistic & Prob. \\
& & & & \\
\hline \hline C & 0.454441 & 0.378011 & 1.202189 & 0.2339 \\
CP & 0.146278 & 0.023358 & 6.262514 & 0.0000 \\
GDP & 0.240473 & 0.035467 & 6.780240 & 0.0000 \\
TB & -0.021016 & 0.049265 & -0.426588 & 0.6712 \\
& & & & \\
\hline \hline
\end{tabular}




\begin{tabular}{lclr} 
R-squared & 0.830792 & Mean dependent var & 4.983846 \\
Adjusted R-squared & 0.822470 & S.D. dependent var & 0.194508 \\
S.E. of regression & 0.081955 & Akaike info criterion & -2.105737 \\
Sum squared resid & 0.409711 & Schwarz criterion & -1.971929 \\
Log likelihood & 72.43646 & Hannan-Quinn criter. & -2.052941 \\
F-statistic & 99.83408 & Durbin-Watson stat & 0.929594 \\
Prob(F-statistic) & 0.000000 & & \\
\hline
\end{tabular}

Dependent Variable: REER

Method: Least Squares

Date: 04/13/17 Time: 13:19

Sample: 2000Q1 2016Q1

Included observations: 65

\begin{tabular}{ccccc}
\hline \hline Variable & Coefficient & Std. Error & t-Statistic & Prob. \\
& & & & \\
\hline C & 0.425676 & 0.369487 & 1.152074 & 0.2537 \\
GP & 0.146745 & 0.023178 & 6.331314 & 0.0000 \\
& 0.242030 & 0.035045 & 6.906263 & 0.0000 \\
\hline \hline R-squared & & & & \\
Adjusted R-squared & 0.824812 & S.D. dependent var & 0.194508 \\
S.E. of regression & 0.081412 & Akaike info criterion & -2.133528 \\
Sum squared resid & 0.410933 & Schwarz criterion & -2.033171 \\
Log likelihood & 72.33965 & Hannan-Quinn criter. & -2.093931 \\
F-statistic & 151.6611 & Durbin-Watson stat & 0.946746 \\
Prob(F-statistic) & 0.000000 & & \\
\hline \hline
\end{tabular}

Attachment 2. Multicollinearity test

\begin{tabular}{|c|c|c|c|c|}
\hline & REER & $\mathbf{C P}$ & GDP & TB \\
\hline REER & 1 & & & \\
\hline $\mathbf{C P}$ & $\begin{array}{c}0.8364967 \\
8495069\end{array}$ & 1 & & \\
\hline GDP & $\begin{array}{c}0.8488582 \\
5068873\end{array}$ & $\begin{array}{c}0.7110511 \\
3557115\end{array}$ & 1 & \\
\hline TB & $\begin{array}{c}-0.1992032 \\
1472616\end{array}$ & $\begin{array}{c}-0.1679871 \\
79185984\end{array}$ & $\begin{array}{c}-0.1907709 \\
51729952\end{array}$ & 1 \\
\hline
\end{tabular}

\section{Attachment 3. Normality test}
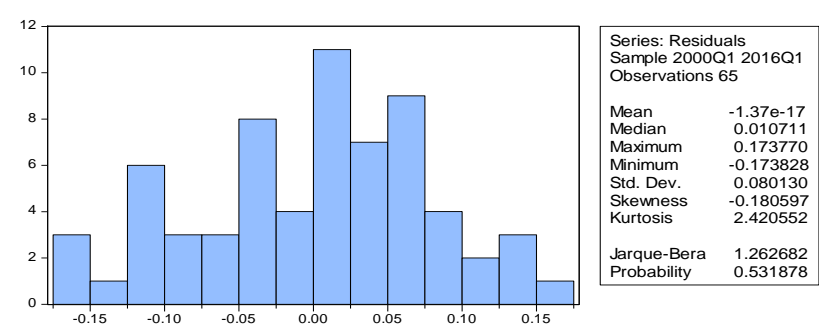

Attachment 4. Johansen Cointegration test results

Sample (adjusted): 2000Q4 2016Q1

Included observations: 62 after adjustments

Trend assumption: Linear deterministic trend

Series: REER CP GDP TB

Lags interval (in first differences): 1 to 2

Unrestricted Cointegration Rank Test (Trace)

\begin{tabular}{|c|c|c|c|c|}
\hline Hypothesized & & Trace & 0.05 & \\
\hline No. of $\mathrm{CE}(\mathrm{s})$ & Eigenvalue & Statistic & Critical Value & Prob.** \\
\hline None & 0.384923 & 42.36265 & 47.85613 & 0.1488 \\
\hline At most 1 & 0.118601 & 12.23021 & 29.79707 & 0.9236 \\
\hline At most 2 & 0.061202 & 4.403022 & 15.49471 & 0.8684 \\
\hline At most 3 & 0.007831 & 0.487434 & 3.841466 & 0.4851 \\
\hline Trace test inc & dicates no coi & tegration at & he 0.05 level & \\
\hline$*$ denotes rej & jection of the & ypothesis at & he 0.05 level & \\
\hline
\end{tabular}

Unrestricted Cointegration Rank Test (Maximum Eigenvalue)

\begin{tabular}{lllll}
\hline \hline Hypothesized & Max-Eigen & 0.05 & \\
No. of CE(s) Eigenvalue & Statistic & Critical Value Prob.** \\
& & & & \\
\hline \hline None * & 0.384923 & 30.13244 & 27.58434 & 0.0230 \\
At most 1 & 0.118601 & 7.827192 & 21.13162 & 0.9140 \\
At most 2 & 0.061202 & 3.915588 & 14.26460 & 0.8681 \\
At most 3 & 0.007831 & 0.487434 & 3.841466 & 0.4851 \\
\hline \hline
\end{tabular}

Max-eigenvalue test indicates 1 cointegrating eqn(s) at the 0.05 level 
$*$ denotes rejection of the hypothesis at the 0.05 level

**MacKinnon-Haug-Michelis (1999) p-values

Unrestricted Cointegrating Coefficients (normalized by $b^{\prime *} \mathrm{~S} 11^{*} \mathrm{~b}=\mathrm{I}$ ):

\begin{tabular}{llll}
\hline \hline REER & CP & GDP & TB \\
-17.63465 & 1.495250 & 6.933448 & 0.086204 \\
2.193216 & -1.530446 & 3.613241 & 3.168610 \\
0.734287 & -2.519033 & 1.734794 & -0.493970 \\
4.201982 & -1.170234 & 0.558525 & -5.151328 \\
\hline \hline
\end{tabular}

Unrestricted Adjustment Coefficients (alpha):

\begin{tabular}{|c|c|c|c|c|}
\hline D(REER) & 0.019673 & -0.009747 & -0.001450 & -0.000934 \\
\hline $\mathrm{D}(\mathrm{CP})$ & -0.033759 & -0.012855 & 0.026295 & -0.004361 \\
\hline $\mathrm{D}(\mathrm{GDP})$ & -0.054286 & -0.011826 & -0.033836 & -0.011278 \\
\hline $\mathrm{D}(\mathrm{TB})$ & -0.026279 & -0.027332 & -0.008375 & 0.005115 \\
\hline $\begin{array}{l}1 \\
\text { Equation(s): }\end{array}$ & \multicolumn{2}{|c|}{$\begin{array}{l}\text { CointegratingLog } \\
\text { likelihood }\end{array}$} & 215.4988 & \\
\hline
\end{tabular}

Normalized cointegrating coefficients (standard error in parentheses)

$\begin{array}{llll}\text { REER } & \text { CP } & \text { GDP } & \text { TB } \\ 1.000000 & -0.084790 & -0.393172 & -0.004888 \\ & (0.02865) & (0.05236) & (0.05965)\end{array}$

Adjustment coefficients (standard error in parentheses)

$\begin{array}{ll}\text { D(REER) } & -0.346918 \\ & (0.09675) \\ \text { D(CP) } & 0.595328 \\ & (0.31829) \\ \text { D(GDP) } & 0.957308 \\ & (0.49419) \\ \text { D(TB) } & 0.463415 \\ & (0.26664)\end{array}$

\begin{tabular}{lcc}
\hline \hline 2 & CointegratingLog & \\
Equation(s): & likelihood & 219.4124 \\
& & \\
\hline \hline
\end{tabular}

Normalized cointegrating coefficients (standard error in parentheses)

$\begin{array}{llll}\text { REER } & \text { CP } & \text { GDP } & \text { TB } \\ 1.000000 & 0.000000 & -0.675425 & -0.205394 \\ & & (0.08166) & (0.15821) \\ 0.000000 & 1.000000 & -3.328829 & -2.364726\end{array}$

(0.87152) (1.68845)

Adjustment coefficients (standard error in parentheses)

$\begin{array}{lll}\mathrm{D}(\mathrm{REER}) & -0.368296 & 0.044333 \\ & (0.09449) & (0.01138) \\ \mathrm{D}(\mathrm{CP}) & 0.567135 & -0.030804 \\ & (0.31917) & (0.03843) \\ \mathrm{D}(\mathrm{GDP}) & 0.931370 & -0.063071 \\ & (0.49714) & (0.05986) \\ \mathrm{D}(\mathrm{TB}) & 0.403471 & 0.002537 \\ & (0.26012) & (0.03132)\end{array}$

\begin{tabular}{lrr}
\hline \hline 3 & CointegratingLog & \\
Equation(s): & likelihood & 221.3702 \\
& \\
\hline \hline
\end{tabular}

Normalized cointegrating coefficients (standard error in parentheses)

\begin{tabular}{|c|c|c|c|}
\hline REER & $\mathrm{CP}$ & GDP & $\mathrm{TB}$ \\
\hline 1.000000 & 0.000000 & 0.000000 & $\begin{array}{l}0.485975 \\
(0.46562)\end{array}$ \\
\hline 0.000000 & 1.000000 & 0.000000 & $\begin{array}{l}1.042687 \\
(1.80469)\end{array}$ \\
\hline 0.000000 & 0.000000 & 1.000000 & $\begin{array}{l}1.023607 \\
(0.83726)\end{array}$ \\
\hline Adjustmen & coefficients (s & andard error & parentheses) \\
\hline D(REER) & $\begin{array}{c}-0.369361 \\
(0.09451)\end{array}$ & $\begin{array}{l}0.047986 \\
(0.01756)\end{array}$ & $\begin{array}{l}0.098664 \\
(0.04255)\end{array}$ \\
\hline $\mathrm{D}(\mathrm{CP})$ & $\begin{array}{l}0.586443 \\
(0.31279)\end{array}$ & $\begin{array}{r}-0.097043 \\
(0.05813)\end{array}$ & $\begin{array}{r}-0.234897 \\
(0.14085)\end{array}$ \\
\hline $\mathrm{D}(\mathrm{GDP})$ & $\begin{array}{l}0.906525 \\
(0.49052)\end{array}$ & $\begin{array}{l}0.022164 \\
(0.09115)\end{array}$ & $\begin{array}{r}-0.477818 \\
(0.22087)\end{array}$ \\
\hline $\mathrm{D}(\mathrm{TB})$ & $\begin{array}{l}0.397321 \\
(0.25952)\end{array}$ & $\begin{array}{l}0.023633 \\
(0.04823)\end{array}$ & $\begin{array}{r}-0.295486 \\
(0.11686)\end{array}$ \\
\hline
\end{tabular}

